\title{
Penerapan Padi-Itik Pada Berbagai Sistem Tanam dalam Mengendalikan Serangga Hama di Tanaman Padi (Oryza sativa L)
}

\author{
Sumini ${ }^{1}$, Etty Safriyani ${ }^{2}$, Holidi $^{3}$, Sutejo ${ }^{4}$, Samsul Bahri ${ }^{5}$, dan Riyanto ${ }^{6}$ \\ 1,2,3,4,5,6 Fakultas Pertanian Universitas Musi Rawas, jl. Pembangunan Komplek Perkantoran \\ Pemda Mura, Lubuk Linggau Timur, Sumatera Selatan \\ 1Email : sumini@fpunmura.ac.id
}

\begin{abstract}
This study aimed to evaluate the application of the paddy-ducks in various cropping systems by controlling pests in rice plants. It was conducted in an irrigated paddy field in S. Kertosari Village, Musi Rawas Regency started from August to November 2016 using an experimental method with a split plot design by 2 treatments and 3 times of repetition. The ducks' treatment (I) as the main plot and the cropping system (S) as sub plots. The treatment of ducks (I) as the main plot includes $10=$ without ducks (Control), $I 1=$ Paddy-Ducks. On the other hand, the cropping system treatment (S) as sub plot includes S1 = Tegel System, S2 = Jajar Legowo 2:1, S3 = Jajar Legowo 3:1, S4 = Jajar Legowo 4:1, S5 = Jajar Legowo 5:1. The results showed that the treatment of ducks and cropping systems had significantly different results on the population of brown planthopper pests, but were not significantly $p<0,05$ different in the population of rice stem borer pests. The combination of the Without ducks treatment (I0) and the Tegel Cropping System (IOS1) had the highest percentage of the brown planthopper and rice stem borer attack. In Without ducks' treatment (I0), the highest pest population was 3,03 brown planthopper and 2,50 stem borer. In the S1 Tegel Planting System, the highest pest population was 2,53 brown planthopper and rice stem borer and up to 2,54 in S4 treatment. The treatment of ducks (I1), the cropping system jajar legowo 2:1 (S2) and the combination of duck and cropping system jajar legowo 2:1 (I1S2) had the best results to all variables and are able to suppress the population and the percentage of pest attacks.
\end{abstract}

Keywords: Brown planthopper, Cropping System, Ducks, Paddy rice, Pest, Stem borer.

\begin{abstract}
ABSTRAK
Penelitian bertujuan untuk mengevaluasi penerapan padi-itik pada berbagai sistem tanam dalam mengendalikan hama di tanaman padi. Penelitian dilaksanakan di lahan sawah irigasi di Desa S.Kertosari Kabupaten Musi Rawas dari bulan Agustus sampai bulan November 2016. Penelitian menggunakan metode Eksperimental dengan Rancangan Petak Terbagi (split plot desing) dengan 2 perlakuan dan 3 kali ulangan. Perlakuan itik (I) sebagai petak utama dan sistem tanam (S) sebagai anak petakan. Perlakuan itik (I) sebagai petak utama meliputi I0 = Tanpa itik (Kontrol), I1 = Padi-Itik. Sedangkan perlakuan sistem tanam (S) sebagai anak petakan meliputi $\mathrm{S} 1=$ Sistem Tegel, S2 = Jajar Legowo 2:1, S3 = Jajar Legowo 3:1, S4 = Jajar Legowo 4:1, S5 = Jajar Legowo 5:1. Hasil penelitian menunjukan bahwa perlakuan itik dan sistem tanam memberikan hasil yang berbeda nyata pada populasi hama wereng coklat namun berbeda tidak nyata pada hama penggerek batang padi. Pesentase serangan hama wereng coklat dan penggerek batang padi tertinggi pada kombinasi perlakuan tanpa itik dan sistem tanam tegel (IOS1). Populasi hama tertinggi pada perlakuan tanpa itik (I0) yaitu wereng coklat sebanyak 3,03 ekor dan penggerek batang padi 2,50 ekor. Populasi hama tertinggi pada perlakuan sistem tanam tegel S1 yaitu wereng coklat sebanyak 2,53 ekor dan penggerek batang padi pada perlakuan S4 yaitu 2,54 ekor. Perlakuan itik (I1) dan sistem tanam jajar legowo 2:1 (S2) serta kombinasi perlakuan itik dan sistem tanam jajar legowo 2:1 (IIS2) memberikan hasil terbaik terhadap semua peubah serta mampu menekan populasi dan persentase serangan hama.
\end{abstract}

Kata Kunci : Itik, Padi, Penggerek batang, Sistem Tanam, Wereng coklat. 


\section{Pendahuluan}

Padi (Oryza sativa L) merupakan salah satu tanaman pangan yang menjadi sumber makanan pokok bagi penduduk Indonesia, untuk mengatasi kebutuhan tersebut maka perlu adanya peningkatan produksi padi baik secara kualitas maupun kuantitas. Namun salah satu yang menjadi kendala dalam melakukan peningkatan produksi padi adalah kerusakan yang disebabkan oleh serangga hama. Hama penting yang menyerang tanaman padi ialah hama wereng coklat dan penggerek batang padi (Misnaheti et al., 2010).

Wereng coklat merupakan serangga hama yang mempunyai genetik plastisitas yang tinggi sehingga mampu beradaptasi dengan berbagai lingkungan dalam waktu yang relatif singkat. Perubahan biotipe yang disebabkan adanya adaptasi yang berkepanjangan merupakan salah satu faktor dalam peledakan populasi hama wereng (Effendi, 2009). Serangan hama wereng pada tanaman padi terjadi secara langsung dengan menghisap cairan sel tanaman dan secara tidak langsung hama wereng dapat menstransfer virus kerdil dengan rentang efesiensi penularan antara 35 - 83\% (Baehaki dan Mejaya, 2015).

Selain hama wereng coklat, hama penggerek batang padi juga mampu merusak tanaman padi pada awal fase vegetatif sampai mencapai 30\%. Hal ini disebabkan karena serangan penggerek batang padi (sundep) pada fase vegetative yaitu menyerang pada titik tumbuh pada tanaman muda. Sedangkan pada fase generatif menyerang malai dengan bulir hampa (beluk) dan terlihat berwarna putih (Suharto, 2010). Kehilangan hasil yang disebabkan hama penggerek batang padi mampu mencapai $10-30 \%$, bahkan dapat menyebabkan tanaman menjadi puso (Ratih et al., 2014).

Upaya yang dilakukan untuk mengendalikan berbagai jenis serangga hama tersebut dengan menggunakan musuh alami (natural enemy). Musuh alami serangga hama umumnya dari jenis serangga dan laba-laba dan dominan dari golongan predator. (Kartoharjono, 2011). Pertanian terintegrasi atau pertanian campuran merupakan konsep pertanian yang mendukung pertanian berkelanjutan dengan cara melibatkan tanaman dan hewan dalam suatu lahan yang sama. Tujuan utama dari pertanian terintegrasi adalah mengurangi input eksternal, karena saling mendukung antar satu komponen dengan komponen lainya (Manjunatha et al., 2014).

Menurut Kalpana et al., (2016) bahwa pertanian terintegrasi antara tanaman padi dengan hewan bertujuan untuk memaksimalkan dalam pemanfaatan sumberdaya alam, mengefisiensikan modal, tenaga dan waktu guna menghasilkan lebih dan satu komoditas. Beberapa keuntungan lain dari pertanian terintegrasi adalah produktivitas lahan yang meningkat, meenghasilkan devirsifikasi produk, memperbaiki kesuburan tanah, memperbaiki sifat fisik tanah, mengurangi gulma, hama dan penyakit (Surahman dan Sudradjat, 2009). 
Belakangan ini salah satu pertanian terintegrasi yang telah diterapkan adalah budidaya tanaman padi-itik. Pemanfaatan itik sebanyak 600 ekor/hektar dalam budidaya tanaman padi, selain mampu meningkatkan pertumbuhan dan produksi padi mencapai $28 \%$ dari budidaya non itik, juga dapat mengurangi populasi dan serangan dari hama utama pada tanaman padi (Sumini et al, 2019).

Selain dengan cara melibatkan tanaman dan hewan untuk meningkatkan produksi padi, peningkatan produksi padi juga dapat dicapai dengan menerapkan berbagai sistem tanam seperti sistem tanam legowo, yaitu sistem tanam persegi panjang yang dimodifikasi. Menurut Praptana dan Yasin (2008) bahwa penanaman dengan sistem tanam jajar legowo mampu menekan populasi dan serangan hama karena aktivitas pemencaran serangga hama akan tertekan disebabkan adanya baris kosong pada tanaman. Hal yang sama di kemukakan oleh Widiarti et al (2004), bahwa sistem tanam dengan jajar legowo tipe 2:1 mampu menurunkan populasi dan presentase serangan hama. Penelitian ini bertujuan untuk mengevaluasi tentang penerapan padi-itik pada berbagai sistem tanam dalam mengendalikan serangga hama di tanaman padi (Oryza sativa L).

\section{Metode Penelitian}

Penelitian dilaksanakan di lahan sawah irigasi di Desa S. Kertosari Kecamatan Purwodadi Kabupaten Musi Rawas pada ketinggian tempat 90 meter di atas permukaan laut dari bulan Agustus 2016 sampai bulan November 2016. Penelitian menggunakan metode Eksperimen dengan Rancangan Petak Terbagi (split plot design) dengan 2 perlakuan dan 3 kali ulangan. Adapun faktor perlakuan yang digunakan adalah : Perlakuan Itik ( I ) sebagai petak utama yaitu 10 = Tanpa itik (Kontrol) dan I1 = Padi-Itik. Perlakuan sistem tanam ( $\mathrm{S}$ ) sebagai anak petak yaitu : S1 = Sistem Tegel, S2 = Jajar Legowo 2:1, S3 = Jajar Legowo 3:1, S4 = Jajar Legowo 4:1, S5 = Jajar Legowo 5:1.

Pada penelitian terdapat 10 kombinasi perlakuan dan 3 kali ulangan sehingga didapat 30 unit percobaan, setiap unit percobaan diambil 5 tanaman sampel. Setelah 10 HST setiap petakan diberi itik umur 20 hari sebanyak 8 ekor,untuk 3 hari petama itik dilepaskan selama 3 jam yang dilepaskan siang hari, hari ke 4 sampai padi mengeluarkan malai itik dilepaskan dari pukul 07.00 pagi sampai pukul 05.00 sore WIB. Pengambilan Hama dan Arthropoda ditajuk dilakukan saat tanaman berumur 14 hst sampai 70 hst, pengamatan di lakukan setiap 14 hari sekali yang dilakukan pada pukul 06.00-07.30 WIB. Pengambilan sampel dilakukan dengan cara mengunakan jaring serangga dan dilakukan identifikasi di Laboratorium Hama dan Penyakit, Fakultas Pertanian, Universitas Musi Rawas. Parameter yang diamati adalah populasi hama wereng coklat, populasi hama penggerek batang padi, persentase serangan hama wereng coklat, persentase serangan 
hama penggerek batang padi dan produksi per rumpun. Persentase serangan dihitung dengan menggunakan rumus sebagai berikut:

Jumlah anakan yang terserang

Persentase Serangan $=$ $\times 100 \%$

Jumlah anakan perumpun

Data dianalisis menggunakan Analysis of Varian (Anova) dan apabila terdapat beda nyata akan dilakukan uji lanjut dengan uji BNT pada taraf $5 \%$.

\section{Hasil dan Pembahasan}

\section{Populasi Hama Wereng Coklat (ekor)}

Hasil analisis keragaman terhadap pengaruh itik (I) dan sistem tanam (S) terhadap populasi hama wereng cokelat berpengaruh nyata $(P<0,05)$, namun berpengaruh tidak nyata pada perlakuan interaksi (IS). Hasil uji BNJ menunjukan bahwa perlakuan tanpa itik (I0) berbeda nyata dengan perlakuan itik (I1). Populasi wereng coklat tertinggi pada perlakuan tanpa itik (I0) yaitu 3,03 ekor dan nilai terendah pada perlakuan itik (I1) yaitu 1,72 ekor. Pada perlakuan sistem tanam, perlakuan S1 berbeda nyata dengan S2, tapi berbeda tidak nyata dengan perlakuan S3, S4 dan S5. Populasi wereng coklat tertinggi terdapat pada perlakuan S1 yaitu 3,16 ekor dan terendah pada S2 yaitu 2,27 ekor. Sedangkan interaksi kedua perlakuan, menghasilkan populasi wereng coklat tertinggi pada perlakuan I1S1 yaitu 3,16 ekor dan terendah pada I1S2 yaitu 1,61 ekor, seperti disajikan pada tabel 1.

Tabel 1. Hasil uji BNJ dan tabulasi data dari perlakuan itik (I), sistem tanam(S) dan interaksi ke dua perlakuan(IS) terhadap populasi wereng coklat

\begin{tabular}{|c|c|c|c|c|c|c|}
\hline \multirow[b]{2}{*}{ Itik (I) } & \multicolumn{5}{|c|}{ Sistem tanam (S) } & \multirow[t]{2}{*}{ Rerata I } \\
\hline & S1 & S2 & S3 & S4 & S5 & \\
\hline 10 & 3.16 & 2.93 & 2.99 & 2.96 & 3.09 & $3.03 b$ \\
\hline 11 & 1.90 & 1.61 & 1.75 & 1.63 & 1.71 & $1.72 \mathrm{a}$ \\
\hline
\end{tabular}

$\begin{array}{llllll}\text { Rerata S } & 2.53 \mathrm{~b} & 2.27 \mathrm{a} & 2.37 \mathrm{a} & 2.29 \mathrm{a} & 2.40 \mathrm{~b}\end{array}$

Keterangan: BNJ I 5\% = 1.07, BNJ S 5\% = 0.15. Angka-angka yang diikuti oleh huruf yang sama pada kolom dan baris yang sama menunjukkan perbedaan yang tidak nyata pada taraf uji $5 \%$

Hasil tabulasi menunjukan bahwa populasi hama wereng coklat terendah pada perlakuan itik (I1). Hal ini diduga keberadaan itik selain berperan dalam menambah unsur hara juga mampu menekan populasi hama. Aktivitas itik di sawah selain mampu meningkatkan kadar oksigen dalam tanah juga dapat menekan populasi hama (Suwandi, 2008). Sedangkan populasi hama wereng coklat tertinggi pada perlakuan tanpa itik (I0). Hal ini diduga tidak adanya aktivitas itik sebagai musuh alami bagi hama sehingga mengakibatkan tingginya populasi di tanaman padi. Hal ini sesuai dengan pernyataan 
Holidi dan Safriyani (2015), bahwa itik berperan sebagai predator yang mampu mengendalikan hama karena hama dapat menjadi makanan itik.

Populasi hama wereng coklat terendah pada perlakuan sistem tanam jajar legowo 2:1 (S2). Hal ini disebabkan penggunaan sistem tanam jajar legowo 2:1 (S2) mampu menekan populasi dan serangan dari serangga hama. Praptana dan Yasin (2008) mengemukakan bahwa pada sistem tanam jajar legowo 2:1 mengakibatkan aktivitas pemencaran serangga hama akan tertekan karena adanya baris kosong pada tanaman.

\section{Populasi Penggerek Batang Padi (ekor)}

Hasil analisis keragaman pengaruh itik (I) dan sistem tanam (S) terhadap populasi hama penggerek batang padi berpengaruh tidak nyata pada semua perlakuan. Hal ini di duga itik tidak mampu dan kesulitan dalam menjangkau larva hama penggerek batang padi yang hidup didalam batang tanaman, sehingga keberadaan itik pada petak yang diaplikasikan itik dengan yang tidak diaplikasikan itik memberikan pengaruh yang sama dan menjadi kurang efektif.

Berdasarkan tabulasi data menunjukan bahwa perlakuan tanpa itik (I0) memberikan populasi tertinggi yaitu 2,50 ekor dan terendah pada I1 yaitu 2,25 ekor. Pada perlakuan S4 menghasilkan populasi tertinggi yaitu 2,54 dan terendah pada perlakuan S2 yaitu 2,28. Sedangkan interaksi kedua perlakuan menghasilkan populasi tertinggi pada perlakuan I0S5 yaitu 2,60 dan terendah I1S2 yaitu 2,13, seperti disajikan pada tabel 2.

Tabel 2. Hasil uji BNJ dan tabulasi data dari perlakuan itik (I), sistem tanam(S) dan interaksi ke dua perlakuan(IS) terhadap populasi penggerek batang padi

\begin{tabular}{ccccccc}
\hline \multirow{2}{*}{ Itik } & \multicolumn{6}{c}{ Sistem tanam (S) } \\
\cline { 2 - 6 } & S1 & S2 & S3 & S4 & S5 & \\
\hline 10 & 2.43 & 2.42 & 2.46 & 2.57 & 2.60 & 2.50 \\
I1 & 2.29 & 2.13 & 2.18 & 2.50 & 2.16 & 2.25 \\
\hline Rerata S & 2.36 & 2.28 & 2.32 & 2.54 & 2.38 & \\
\hline
\end{tabular}

Secara tabulasi perlakuan tanpa itik (I0) mempunyai populasi hama tertinggi. Hal ini disebabkan pada petak tersebut tidak ada itik yang diberikan sehingga tidak adanya aktivitas itik disawah dalam mencari makanan dan dapat menyebabkan populasi hama menjadi meningkat. Menurut Hossain et al., (2005) sistem pertanian terpadu padi-itik sangat menguntungkan dikarenakan peran itik sebagai pestisidator (musuh alami) yang memperoleh makanan dari serangga-serangga yang hidup di ekosistem pertanaman padi.

Pada perlakuan sistem tanam jajar legowo 2:1 (S2) mampu menekan populasi hama, hal ini dikarenakan pada sistem tanam jajar legowo 2:1 mempunyai ruang dan jarak yang jauh yang disebabkan adanya baris yang kosong sehingga akan mempengaruhi hama untuk terbang dari rumpun yang satu ke rumpun yang lain.

\section{Presentase Serangan Hama Wereng Coklat (\%)}

Serangan hama wereng coklat terdeteksi pada 3 fase pertanaman padi, yaitu; 42 
HST, 56 HST, dan 70 HST. Persentase serangan hama wereng coklat pada tanaman padi tertinggi pada perlakuan IOS1 yaitu 9,39 dan persentase serangan terendah pada perlakuan I1S2 yaitu 5,09, seperti disajikan pada gambar 1 .

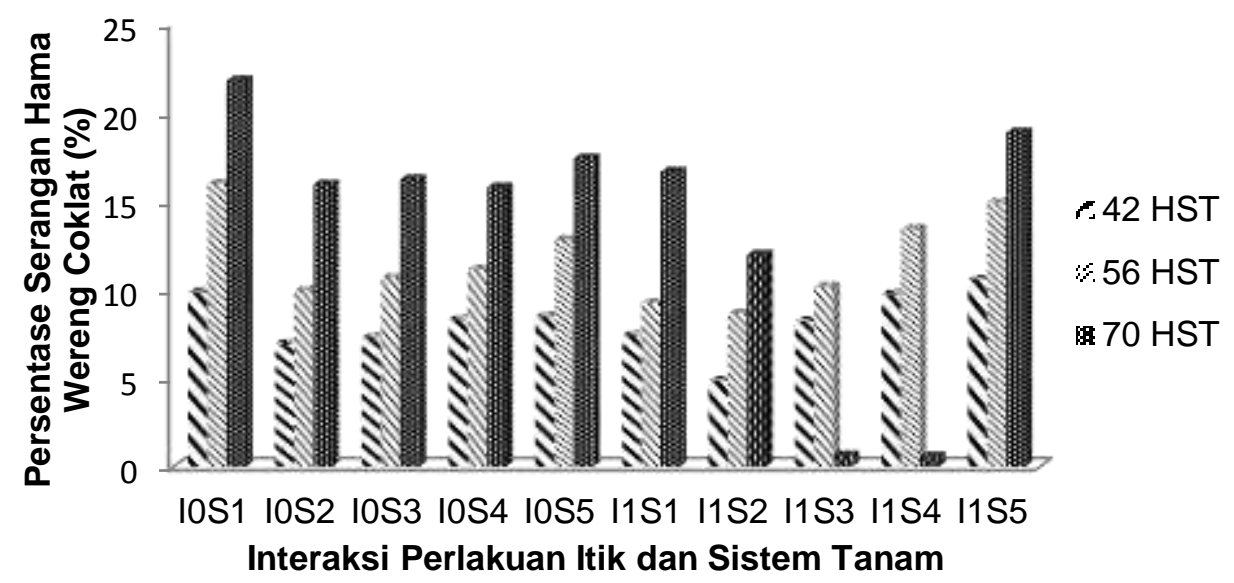

Gambar 1. Rata-rata persentase serangan hama wereng coklat pada perlakuan itik (I), sistem tanam (S).

\section{Presentase Serangan Hama Penggerek Batang Padi (\%)}

Serangan hama wereng coklat terdeteksi pada 3 fase pertanaman padi, yaitu; 42 HST, 56 HST, dan 70 HST. Persentase serangan hama penggerek batang padi pada tanaman padi tertinggi pada perlakuan I0S1 yaitu 6,72 dan persentase serangan terendah pada perlakuan I0S3 yaitu 4,92, seperti disajikan pada gambar 2 .



Gambar 2. Rata-rata persentase serangan hama walang sangit pada perlakuan itik (I), sistem tanam (S).

Persentase serangan hama wereng coklat dan penggerek batang padi menunjukan bahwa kombinasi perlakuan tanpa itik dan sistem tanam tegel (IOS1) memberikan nilai hasil tertinggi yaitu hama wereng coklat sebesar 9,39\% dan hama penggerek batang padi 
sebesar $6,72 \%$. Hal ini disebabkan tidak adanya aktivitas itik di perlakuan dan penggunaan sistem tanam tegel yang tidak mempunyai ruang dan baris yang kosong serta jumlah tanaman yang rapat akan mengakibatkan kurangnya intensitas cahaya matahari yang sampai ke tanaman mengakibatkan tingginya kelembaban dan menyebabkan populasi hama dan persentase serangannya menjadi tinggi.

Persentase serangan hama menunjukan bahwa kombinasi perlakuan itik dan sistem tanam jajar legowo 2:1 (IS2) memberikan hasil terendah. Hal ini disebabkan itik yang dilepaskan selain dapat menyuburkan tanah juga penggunaan sistem tanam jajar legowo 2:1 (S2) mampu memanfaatkan cahaya matahari bagi tanaman, serta mampu menekan populasi dan persentase serangan hama karena rendahnya kelembaban dibandingkan dengan sistem tanam tegel.

\section{Produksi Per Rumpun}

Hasil uji BNJ menunjukan bahwa perlakuan 11 berbeda nyata dengan 10. Hasil produksi per rumpun tertinggi terdapat pada 11 yaitu 45,96 gram dan produksi per rumpun terendah pada 10 yaitu 42,60 gram, seperti disajikan pada tabel 3 .

Tabel 3. Hasil uji BNJ dan tabulasi data dari perlakuan itik (I), sistem tanam(S) dan interaksi ke dua perlakuan(IS) terhadap produksi per rumpun

\begin{tabular}{|c|c|c|c|c|c|c|}
\hline \multirow{2}{*}{ Itik } & \multicolumn{5}{|c|}{ Sistem tanam (S) } & \multirow[t]{2}{*}{ Rerata I } \\
\hline & S1 & S2 & S3 & S4 & S5 & \\
\hline 10 & 34.87 & 44.53 & 44.20 & 48.93 & 40.47 & $42.60 a$ \\
\hline 11 & 45.20 & 53.27 & 44.53 & 46.67 & 40.13 & $45.96 b$ \\
\hline Rerata S & 40.03 & 48.90 & 44.37 & 47.80 & 40.30 & \\
\hline
\end{tabular}

Berdasarkan hasil analisa keragaman perlakuan Itik $(\mathrm{I})$ berpengaruh nyata $(P<0,05)$ terhadap produksi per rumpun. Hal ini disebabkan adanya aktivitas itik dalam mencari makan sehingga tanah menjadi gembur serta dapat menyediakan unsur hara dikarenakan itik mengeluarkan kotorannya sehingga mampu mempengaruhi pertumbuhan dan produksi dari tanaman padi. Perlakuan sistem tanam (S) berpengaruh tidak nyata terhadap produksi per rumpun. Hal ini diduga penggunaan sistem tanam memberikan pengaruh yang sama terhadap produksi per rumpun karena semua sistem tanam yang ada sama-sama memberikan kondisi yang baik untuk pertumbuhan tanaman. Hal ini sesuai dengan pernyataan Muharam (2013), bahwa setiap populasi tanaman yang mendapatkan intensitas cahaya, iklim makro, air, media perakaran dan unsur hara yang relatif sama akan mengakibatkan pertumbuhan seragam. 
Berdasarkan hasil analisa keragaman interaksi perlakuan itik dan sistem tanam (IOS1) memberikan hasil terendah yaitu 34,87 gram pada peubah produksi per rumpun. Hal ini diduga tidak ada perlakuan itik sehingga unsur hara yang dibutuhkan tanaman belum tercukupi dan rendahnya intensitas cahaya matahari yang sampai ke tanaman dari penggunaan sistem yang terlalu rapat menyebabkan tanaman mengalami pertumbuhan yang kurang maksimal serta mengakibatkan tingginya populasi dan persentase serangan hama.

\section{$4 \quad$ Kesimpulan}

Kombinasi perlakuan itik dan sistem tanam jajar legowo 2:1 menunjukan hasil terbaik terhadap pengendalian populasi hama wereng coklat. Aktifitas itik pada pertanaman padi dapat diduga mengakibatkan penggemburan tanah dan penyediaan unsur hara yang berasal dari kotorannya, yang mengakibatkan adanya peningkatan produksi. Adanya perbedaan sistem tanam yang diterapkan tidak memberikan pengaruh nyata terhadap produksi padi. Hasil ini diperoleh dalam satu musim tanam. Namun, hasil ini dapat digunakan sebagai acuan dalam penerapan kombinasi sistem padi-itik sebagai upaya pengendalian hama terpadu untuk cakupan yang lebih luas.

\section{Daftar Pustaka}

Baehaki, S. E., \& Mejaya, M. J. (2015). Wereng cokelat sebagai hama global bernilai ekonomi tinggi dan strategi pengendaliannya. Iptek Tanaman Pangan, 9(1), 1-12.

Baehaki, S. E. (2015). Hama penggerek batang padi dan teknologi pengendalian. Iptek Tanaman Pangan, 8(1), 1-14.

Effendi, BS. 2009. Strategi pengendalian hama terpadu tanaman padi dalam perspektif praktek pertanian yang baik (Good agricultural practices). Pengembangan Inovasi Pertanian, 2(1),65-78.

Hossain, S. T., Sugimoto, H., Ahmed, G. J. U., \& Islam, M. (2005). Effect of integrated riceduck farming on rice yield, farm productivity, and rice-provisioning ability of farmers. Asian Journal of Agriculture and Development, 2(1362-2016-107647), 7986.

Holidi \& Safriyani, E. (2015). Aplikasi Berbagai Varietas Padi Unggul Pada Pola Pertanian Terpadu Padi Itik. Dalam International Seminar on Promoting Local Resources for Food and Health, 12-13 October, 2015, Bengkulu. ISBN:9786029071184.

Kartohardjono, A. (2011). Penggunaan musuh alami sebagai komponen pengendalian hama padi berbasis ekologi. Pengembangan Inovasi Pertanian, 4(1), 29-46.

Kalpana, M., Singh, S. P., Ashutosh, D., Manisha, C., \& Rajiv, D. (2016). Relative efficiency of rice-fish-duck production under integrated and conventional farming systems. Asian Journal of Animal Science, 11(1), 49-52.

Manjunatha, S. B., Shivmurthy, D., Sunil, A. S., Nagaraj, M. V., \& Basavesha, K. N. (2014). Integrated farming system-an holistic approach: A review. Research and Reviews: Journal of Agriculture and Allied Sciences, 3(4), 30-38. 
Misnaheti, Baco, D., dan Aisyah. (2010). Tren Perkembangan Penggerek Batang Pada Tanaman Di Sulawesi Selatan. Dalam Prosiding Seminar IImiah dan Pertemuan Tahunan PEI dan PFI XX Komisariat Daerah Sulawesi

Muharam. (2013). Kajian Beberapa Jarak Tanam Sistem Legowo dan Cara Pemupukan Terhadap Hasil Padi. Laporan Penelitian. Fakultas Pertanian. Universitas Udayana.

Praptana, R. H., \& Yasin, M. (2015). Epidemiologi dan strategi pengendalian penyakit tungro. Iptek Tanaman Pangan, 3(2).

Ratih, S. I., Karindah, S., \& Mudjiono, G. (2014). Pengaruh sistem pengendalian hama terpadu dan konvensional terhadap intensitas serangan penggerek batang padi dan musuh alami pada tanaman padi. Jurnal Hama dan Penyakit Tumbuhan, 2(3), pp18.

Suharto, H. (2010). Pengendalian Hama Penggerek Batang Padi. Balai Besar Penelitian Tanaman Padi. Puslitbangtan. Badan Litbang Pertanian.

Suwandi. (2008). Integrasi Tiktok Dengan Padi Sawah Di Pinggiran Kota Jakarta. Warta Penelitian dan Pengembangan Pertanian Vol 30 (4).

Sumini, S., Holidi, H., \& Widiyanto, W. (2019). Peningkatan Produktivitas Tanaman Padi Sawah Irigasi Terintegrasi Populasi Itik. Jurnal Agrotek Tropika, 7(1), 247-248.

Surahman, M., \& Sudrajat. (2009). Sistem pertanian terpadu. Naskah akademis: Pengembangan model ecovillage. Departemen Agronomi dan Hortikultura, Fakultas Pertanian Institut Pertanian Bogor. Bogor: IPB

Widiarti, IN., Burhanuddin, A., Darajar, \& Hasanuddin, A. (2004). Status dan program pengendalian terpadu penyakit tungro. Dalam Prosiding seminar nasional ststus program penelitian tungro mendukung keberlanjutan produksi padi Nasional. Makasar, 7 - 8 Sep 2004. 